\title{
The Effect of a Sports Institution's Legal Structure on Sponsorship Income: The Case of Amateur Equestrian Sports in Germany
}

Pamela Wicker ${ }^{1}$, Christian Weingaertner ${ }^{2}$, Christoph Breuer ${ }^{3}$, and Helmut Dietl ${ }^{2}$

${ }^{1}$ Griffith University

${ }^{2}$ University of Zurich

${ }^{3}$ German Sport University Cologne

Pamela Wicker, $\mathrm{PhD}$, is a senior lecturer in the Department of Tourism, Leisure, Hotel and Sport Management. Her research interests include economics of sport consumer behavior, sport participation, and financing of non-profit sport clubs. Christian Weingaertner is a PhD student in the Department of Business Administration. His research interests include economic consequences of property rights allocations in sports and in two- or more-sided markets.

Christoph Breuer, PhD, is a professor of sport management and the head of the Institute of Sport Economics and Sport Management. His primary research interests include sport systems, sport development planning, sponsorship in sport, and development of sport clubs.

Dr. Helmut Dietl is a professor of services and operations management in the Department of Business Administration. His research interests include sport economics, service management, and organization.

\section{Abstract}

Choosing the legal structure of a sports institution is one of the key decisions that sports managers must make. Using platform theory and property rights theory, this paper shows that the choice of legal structure influences the revenue composition of sports institutions. We hypothesized that member associations should receive higher sponsorship revenues than private firms because their legal structure offers better protection against hold-up for sponsors and also for customers/members, which in turn leads to increased attention for the sponsor. We tested this prediction using quantitative data from a nationwide online survey of equestrian sports institutions in Germany. In 2009, $n=574$ private firms and $n=1,165$ member associations completed the same questionnaire. Regression analyses were run to determine whether the legal structure has an impact on sponsorship income. The results confirmed the hypothesis that the legal structure has a significant impact on sponsorship income.

Keywords: sponsorship, property rights, platform theory, sport club, private firm 


\section{Introduction}

The increasing success of English clubs in European professional football is currently driving a public discussion in Germany about the competitiveness of its local clubs (Franck, 2010b). Experts have often cited the legal structure of the clubs as a core reason for their poor game performance (Kicker, 2010). German football clubs are restricted by the $50+1$ directive, which ensures that the clubs are organized as, or at least dominated by, member associations. Member associations are characterized by their own legal personality, democratic structure, and non-profit status. In contrast, the English clubs are free to select their own legal structures and, as a result, mainly choose to act as private firms. Private firms are defined as profit-oriented institutions that fit the classic model of capitalistic, privately owned firms. Judging by the success of English clubs in recent years, private firms appear to be superior to member associations. However, a more sophisticated analysis is necessary.

In previous economic research, there was no agreement among scholars regarding the influence of the legal structure on the performance of a firm. For example, while neither Demsetz and Villalonga (2001) nor Himmelberg, Hubbard, and Palia (1999) could find an effect in their studies, Karpoff (2001) and Frick (2004) demonstrated that effects are measurable when a homogeneous dataset is used. However, none of the legal structures seem to be superior in every respect. The choice of a legal structure is determined by trade-offs, as each legal structure brings along certain advantages and disadvantages. Demsetz and Lehn (1985) tried to identify the forces that determine the choice for a specific legal structure. Hansmann (1986) showed advantages with regard to the perception of different legal structures. For example, profit-oriented private firms are considered to be more efficient than non-profit organizations. In addition, they have easier access to the capital markets. In contrast, non-profit organizations enjoy higher credibility than profit-oriented institutions.

With regard to sports management, Dilger (2009) evaluated the competitiveness of member associations in professional sports and showed that they do not necessarily backdrop when compared with private firms. Dietl and Weingärtner (2011) reported that the legal structure of professional sports institutions impacts their revenue composition. Professional sports clubs primarily derive their earnings from four different sources: match day/tickets, merchandise, broadcasts, and sponsorships (Deloitte, 2010). The influence of the legal structure on the varying proportions of the institution's revenue sources can be seen by comparing the leading English club, Manchester United, which is organized as a profit-oriented private firm, with the German market leader FC Bayern Munich, which is structured as a non-profit member association. Both clubs have a comparable overall budget of approximately $€ 300 \mathrm{~m}$. Although Manchester United generates $75 \%$ of its budget with broadcasting and match-day revenues, these sources contribute only $45 \%$ of the budget of Bayern Munich. However, the German club outperforms the English club with regard to income from sponsorships and merchandise: $55 \%$ of the annual revenues are derived from these sources, whereas they contribute only 25\% to Manchester United's annual revenues (Deloitte, 2010).

The purpose of this paper is to determine whether these findings with regard to professional football are universally valid and applicable to sports institutions in other sports and in the amateur market. Specifically, this paper analyzes whether sponsor- 
ship revenues differ in amateur equestrian sports according to the legal structure of the sports institution. This focus leads to the following main research question: Are there significant differences in sponsorship revenues between member associations and private firms? The theoretical framework of this study utilizes platform theory to explain the basic mechanisms of value creation activities, such as sponsorships with sports institutions, and to analyze the property rights situation for different legal structures. The empirical evaluation is based on data related to the amateur equestrian sports institutions in Germany, which were originally assessed by the Sports Development Report for Equestrian Sports in Germany (Breuer \& Wicker, 2011). Equestrian sports institutions are particularly useful for answering the research question of this study, as both private firms and member associations are members of the national governing body of equestrian sports in Germany. Thus, both types of institutions can be effectively compared for analytical purposes. Sponsorship is legal for amateur sports institutions in Germany.

\section{Theoretical Framework and Literature Review}

The theoretical framework of this study is based on a combination of platform theory and property rights theory. Combining and applying these theories to the sports management field is a relatively new approach. For this paper, this combination is particularly useful, as both theories contribute significantly to the explanation of differences in sponsorship revenues depending on an institution's legal structure. Platform theory analyzes the specifics of value creation of sports institutions. It explains the multidimensional effects between all market participants and thus enables a full view of the consequences for potential sponsors caused by different legal structures. Property rights theory shows the characteristics of the two legal structures and clarifies their impact on the market participants.

With the aid of platform theory, it is possible to explain the business models of companies or institutions acting as intermediaries between different market participants (Armstrong, 2006; Dietl, 2010). Specifically, this theory demonstrates the ways in which a platform enables interaction among different market participants, which then serves as the key driver of value creation (Lepak et al., 2007; Rysman, 2009). To define this value creation, Zeithaml states that "value is the consumer's overall assessment of the utility of a product based on perceptions of what is received and what is given" (Zeithaml, 1988, p. 14). Platform theory has already been applied to many different industries (e.g., Bakos \& Katsamakas, 2009; Rochet \& Tirole, 2002). Oft-cited examples are the credit card industry and recruitment websites. In the credit card industry, merchants interact with their customers via the platform of the credit card. Recruitment websites, on the other hand, serve as a platform for employers to interact with jobseekers (Eisenmann et al., 2006).

Previous research in sports management has shown that professional sports institutions also act as platforms for value creation (Dietl \& Duschl, 2009; Dietl \& Weingärtner, 2011). Value creation within professional sports institutions is primarily driven by the interactions among the different market participants, such as fans, media, teams/athletes, and sponsors. The institution itself provides the underlying platform or infrastructure (e.g., by building and maintaining a stadium or by setting up a team and taking part in a championship). Value is ultimately created when one 
market participant (e.g., the sponsor) wants to interact with another market participant (e.g., the fans). Figure 1 shows the basic idea of value-creating platforms.

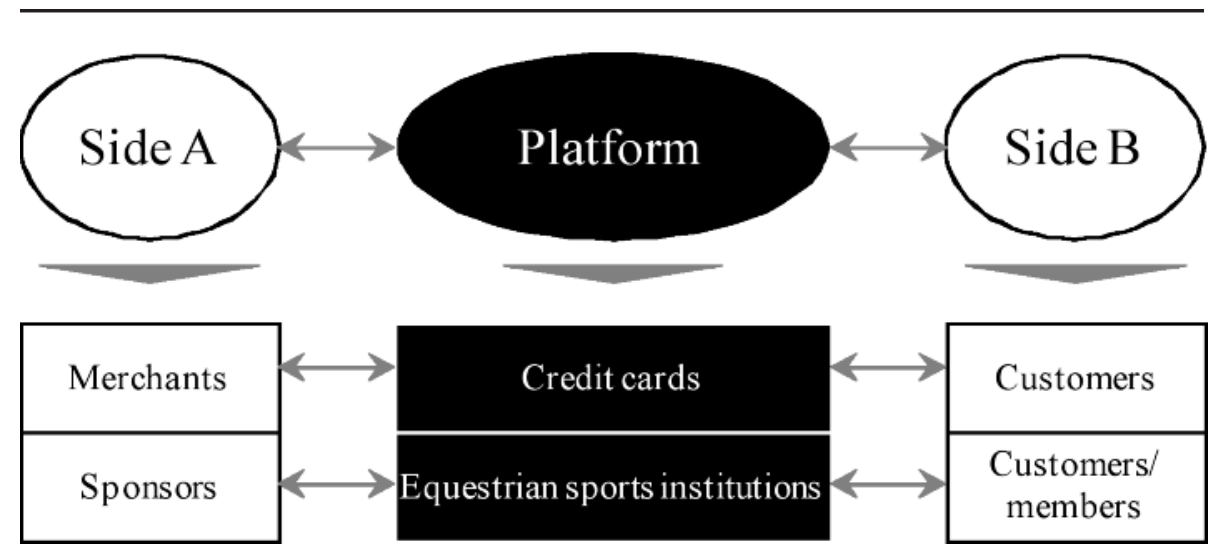

Figure 1: Platforms for Value Creation

To date, this approach has been applied in sports management to the professional sector only, but it can easily be transferred to the amateur sports segment in general or specifically to the example of equestrian sports institutions. The amateur sports institution is surrounded by different market participants as well. The main market participants for equestrian sports institutions are sponsors, active sportspeople who join as members or customers, governments, (local) media, and interested people/spectators. Additional potential stakeholders (e.g., schools or local craft enterprises) are excluded for the purpose of this paper. The institution itself acts as a platform for the interactions among all of the listed participants. Imagine an equestrian sports institution that provides practice and tournament facilities, such as a racetrack or a stadium, and rents out horses on an hourly basis and/or horseboxes for people bringing their own horses. Customers/members can use these facilities to develop their skills. Equipment manufacturers, on the other hand, act as sponsors of the institution to promote their products to the sportspeople or spectators. For example, the sponsors may pay an equestrian sports institution to allow them to construct a perimeter around the racetrack or the stadium that features advertisements. Moreover, the spectators may pay for tickets to the tournaments to watch the sportsmen. In this manner, the equestrian sports institution is able to create value simply by providing a platform for value creation. The value creation mechanism itself is defined by network effects (Eisenmann, Parker, \& van Alstyne, 2008; Rochet \& Tirole, 2003), potential hold-up problems (Dietl, 2010), and the platform strategy regarding openness (Rochet \& Tirole, 2006; Rysman, 2009). Below, we analyze these characteristics in detail.

Network effects determine the value creation potential of different platforms. The stronger these effects, the higher the value creation potential of a platform-mediated network. Network effects arise if an increasing quality or quantity of one market side has a positive effect on the demand towards the network in general (Dietl \& Duschl, 2009). Same-side effects occur if the effect reaches the initial market side. For example, a growing number of customers/members attract other sportspeople to join, as the 
economies of scale allow for superior programs or better training facilities compared with smaller institutions. Another example is the virtuous circle initiated by an increase in spectators, as watching sports events or cheering for the same team/athlete in a larger crowd is an improved experience. Cross-side effects may occur if the growth of one market side leads to higher demand at other market sides. For instance, the greater the number of customers/members in an equestrian sports institution, the more likely (local) media will report on the institution. High media coverage in turn drives the public interest and thus increases the number of spectators attending various sporting events, such as tournaments. A large group of sportspeople and spectators and a large media presence encourage more sponsors to join the network and persuade the government to provide public funds to the institution. Figure 2 summarizes the possible network effects related to amateur equestrian sports institutions.

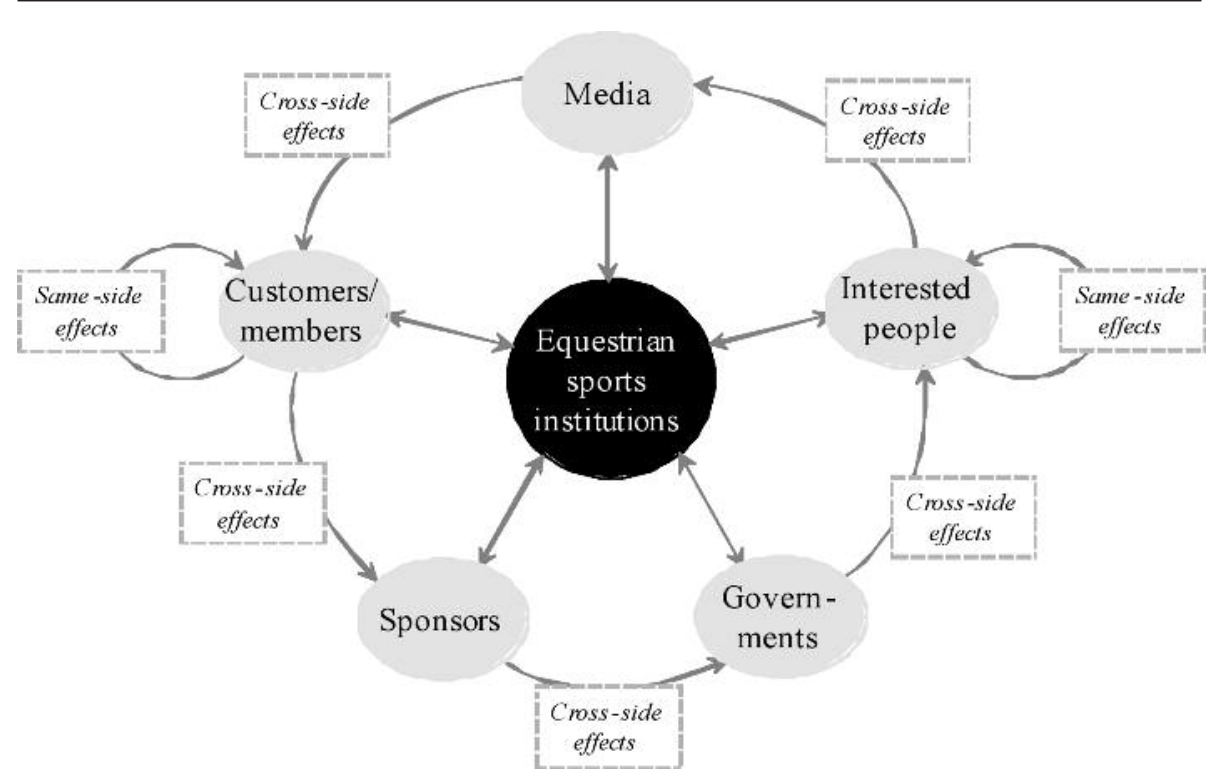

Figure 2: Market Participants and Network Effects with Equestrian Sports Institutions

The decision to join a network, such as an amateur equestrian sports institution, calls for a platform-specific investment by the new participant (Dietl, 2010). The investment of sponsors entails signing a long-term contract, whereas that of customers/members requires certain costs, such as an admission fee. With regard to equestrian sports, the loyalty and level of familiarity between an athlete and a horse can also be considered an investment because the relationship between the horseman and his horse is an important success factor in this sport. An individual investment locks the participants into the specific platform and makes them vulnerable to holdup issues. Hold-up problems occur if one contracting party is at the mercy of another after the initial investment is made. For instance, if an equestrian sports institution greatly raises its hourly fees for renting horses, then the athletes will be in a hold-up situation. These athletes must then choose between two alternatives. If they change 
institutions, they may lose the admission fee that has already been paid. Moreover, they may have to familiarize themselves with new horses. In the alternative scenario, the athletes stick with the institution and pay the higher charges. For the sponsor, a holdup situation is even worse. If many athletes leave the institution after a fee increase, then the sponsor's audience will dramatically decrease. Because the sponsor's investment exists in the form of a long-term contract, the sponsor cannot simply leave the institution together with a group of customers/members. A rational network participant will anticipate this danger and refuse to join the network (Dietl \& Duschl, 2009).

For platform providers, a common method to overcome the danger of hold-up problems for its participants is to choose a strategy based on openness. A platform can be considered open if there are no restrictions regarding the participation, usage, and development of the network (Eisenmann et al., 2008). In contrast, a closed platform imposes hurdles for each of these aspects. Open platforms enhance network mobilization because of the lack of potential hold-up situations for the participants (Dietl \& Duschl, 2009). The openness of the platforms is not binary; rather, it may differ across the various market sides, and platform ownership must also be analyzed (Eisenmann et al., 2008). The media side of the platforms can be considered open, as there are no limitations with regard to the media coverage of amateur sports institutions. However, the sponsor side is closed because participation as a sponsor is restricted to those who sign a sponsorship contract and pay for the partnership. The choice of a specific legal structure influences the degree of openness with regard to platform ownership (Dietl \& Weingärtner, 2011). Therefore, the chosen legal structure is a part of the openness strategy enacted by the platform managers/owners.

The legal structure also influences the allocation of property rights. A property right can be defined as "a method of assigning to particular individuals the 'authority' to select, for specific goods, any use from an unprohibited class of uses" (Alchian, 1977, p. 130). Property rights determine the authority regarding the usage of a specific good (Picot, Dietl, \& Franck, 2008; Richter \& Furubotn, 2010). Previous studies have focused on various aspects of property rights, such as their allocation within large companies and their impact on corporate governance (e.g., Picot, 1981; Picot \& Michaelis, 1984). The theory has also been applied to various perspectives on professional sports (e.g., Daly \& Moore, 1981; Marbuger, 2002). However, investigations of the property right situation for each legal structure, especially in conjunction with platform theory, are relatively new (Dietl \& Weingärtner, 2011) and have not yet been applied to amateur sports. The various types of property rights (Milgrom \& Roberts, 1992) can be differentiated into the following:

a) Residual control consists of the right to make any decisions on the usage or change of a specific good.

b) Residual claim is the right to retain the earnings from a specific good after all liabilities are paid.

c) Transfer right consists of the right to sell or transfer the property rights to a third party.

Each of these rights is linked to a specific object, which is the amateur equestrian sports institution in this study. Thus, these rights can be shared among different people. The analysis of the various legal structures with regard to sponsorship revenues is based on the assumption that sponsors aim for high attention and secure investments 
with low hold-up risks (Dietl \& Weingärtner, 2011; Franck, 2010a). This paper suggests that the distribution of property rights impacts the underlying model of value creation in sports and thus produces different weights for each of the revenue sources (e.g., sponsorships). Below, we evaluate the two legal structures with respect to their property rights situation and the accompanying consequences for their sponsors (Table 1).

The private firms in the German amateur equestrian sports sector are mainly organized as private limited liability companies; few are public limited companies. A key characteristic of private firms is the concentrated allocation of all three above-mentioned types of property rights with the owner(s) (Franck, 2010a). The owner exerts influence directly, by taking over the role of CEO, or in an indirect way, by controlling a management team as chairman of the supervisory board. As a residual claimant, the owner is allowed to collect any profits generated within the sports institution. The transfer right enables the proprietor to sell his or her ownership stake to other persons or organizations. The utility of the institution is mainly derived from its maximization of profits (Franck, 2010b). The choice of this type of legal structure renders the platform less open. In contrast, in the member association, the residual right of control belongs to the members; the residual claim and transfer right do not exist.

The property rights constellation in private firms bears certain risks for potential sponsors (Table 1). First, there is a danger of hold-up for the customers, leading to a reduced audience for the sponsor. Customers have no direct influence on the strategy of an institution. After making an initial investment in a platform, they may be locked into a hold-up situation because of a potential royalty increase or a reduction in training capacities. Moreover, these customers cannot be sure that all of the fees they have paid are reinvested into the facilities of the institution, as the profits can be partially distributed among different entities or entirely allocated to the investor. Rapid strategy changes may occur for various reasons (e.g., a new owner). These factors will lead to a decreasing number of participants, as rational customers will anticipate this risk and either leave the platform or not join at all. Second, sponsors must also address potential hold-up problems. A sponsor is exposed to hazards similar to those faced by

Table 1: Situation for the Sponsor

\begin{tabular}{lll}
\hline Sponsor's aims & Private firm & Member association \\
\hline Attention for the sponsor & $\begin{array}{l}\text { Low } \\
\text { Risk of hold-up for } \\
\text { customers and other } \\
\text { interested people is high }\end{array}$ & $\begin{array}{l}\text { High } \\
\text { Hold-up risk for members } \\
\text { is low due to full control } \\
\text { and requirement of } \\
\text { reinvestment of all funds }\end{array}$ \\
$\begin{array}{l}\text { Sponsor's protection } \\
\text { against hold-up risk }\end{array}$ & $\begin{array}{l}\text { Low } \\
\text { Distribution of money } \\
\text { gathered (partly) through } \\
\text { sponsorships is possible } \\
\text { Rapid strategy changes } \\
\text { are feasible }\end{array}$ & $\begin{array}{l}\text { High } \\
\text { constraint ensures } \\
\text { reinvestment of all funds }\end{array}$ \\
& $\begin{array}{l}\text { Rapid strategy changes } \\
\text { are unlikely }\end{array}$ \\
\hline
\end{tabular}


customers. Being a residual claimant, the owner of the institution can allocate to himself at least part of the money gained through the sponsorship. If the owner uses the transfer right and sells the institution, rapid strategy changes would negatively affect the sponsor because the contracts are usually made on a long-term basis with the institution (Dietl \& Weingärtner, 2011).

In the context of this paper, a member association is defined as an association/legal form with its own legal personality. Most continental European countries use this definition. Member associations allow for collective engagements in financial transactions and other business tasks (Franck, 2010a). Many amateur sports institutions use this legal structure to organize their activities and to construct their legal frameworks. The key characteristic of a member association is its non-profit status. Member associations and other non-profit sports organizations share the same characteristics: a democratic structure, members united by common interests, voluntary membership, emphasis on volunteers, and autonomy (Horch, 1992, 1994). This legal structure makes a platform-mediated network more open. Because of the democratic structure, the residual right of control is given to the members who elect representatives for the day-to-day business of the institution and who vote on important issues during a regularly scheduled meeting of members (Franck, 2010a). The institution's non-profit status and additional legal limitations eliminate the possibilities of residual claims or transfer rights (Dietl, Franck, Hasan, \& Lang, 2007). Because non-profit institutions cannot distribute any profits or benefits from rising stock prices, the member association structure is unappealing to investors. Thus, utility can only be derived from maximizing the welfare of the institution's members (Franck, 2010a).

For sponsors, an institution organized as a member association is attractive because of the increased attention associated with this structure (Table 1). The allocation of the residual right of control secures the influence of the members. As a result, the risk of falling into a hold-up situation is low for them. This low risk leads to a stronger demand by potential members, as more people are willing to invest in the platform. Moreover, the members do not have to fear that any part of their membership fee is distributed (e.g., to any investor) as no residual claim exists. An institution governed as a member association is also a safe investment for potential sponsors. As with the members, the sponsor can be certain that all of his or her funds are invested into the infrastructure of the institution and that nothing is distributed to any investor. The non-existence of any transfer rights renders rapid strategy shifts after ownership changes impossible. Thus, a sponsor may predict the mid-term development of the institution (Dietl \& Weingärtner, 2011).

This comparison shows that member associations have an advantage with respect to sponsors' options and the institution's potential to gain sponsorship revenues. The comparison shows that the goals of the welfare-maximizing member associations are more in accordance with the sponsor's aims than those of private firms. Therefore, it is hypothesized that sports institutions governed as member associations receive higher sponsorship revenues than private firms. This hypothesis will be empirically tested using data from amateur equestrian sports institutions in Germany. 


\section{Method}

\section{Research Context}

This paper conducted an empirical comparison between private firms (in German: "Pferdebetriebe") and member associations (non-profit sports clubs; in German: "Pferdesportvereine") with regard to their sponsorship income in amateur equestrian sports in Germany. Equestrian sports are unique in that both the private firms and the member associations are members of the same national governing body for equestrian sports. In other sports, only member associations are members of the national governing body. Therefore, equestrian sports institutions are highly relevant to the research question posed by this paper. Overall, a total of approximately 3,800 private firms and 7,700 member associations exist in amateur equestrian sports in Germany. The private firms are companies that are owned by individual persons. These firms can be differentiated into agricultural and industrial companies, with approximately 59\% of the private firms being agricultural and $41 \%$ being industrial companies. The firms are relatively small. More than $51 \%$ of the private firms have at most 50 customers, and approximately $18 \%$ have between 51 and 100 customers. Approximately $30 \%$ of the firms have more than 100 customers. The member associations are non-profit organizations that have more members than the private firms. Approximately $26 \%$ of the associations have at most 50 members, approximately $26 \%$ between 51 and 100 members, and approximately 40\% between 100 and 300 members (Breuer \& Wicker, 2011).

\section{Data Collection}

The data for this study were collected from the Sport Development Report for Equestrian Sports 2009 (Breuer \& Wicker, 2011). The Sport Development Report is a third-party research project designed to analyze the development of non-profit sports clubs (i.e., member associations) in Germany. In 2009, this project was extended to include the equestrian sports industry (i.e., member associations and private firms) and was funded by the Fédération Nationale, which is the national governing body for equestrian sports in Germany. This research project was originally designed to provide information about equestrian sports institutions, as no empirical information was available at the time.

The data were collected with a nationwide online survey of amateur equestrian sports institutions in Germany, which lasted from January 12, 2009, to March 8, 2009. The 17 regional governing bodies of equestrian sports made the e-mail addresses of the sports institutions available for this survey. Altogether, the addresses of $n=1,971$ private firms and $n=3,497$ member associations were sent to the project team. All of the sports institutions that had e-mail addresses listed at the regional governing bodies were invited to take part in the survey. However, the total number of institutions included was reduced by dropouts. There were $n=374$ dropouts for private firms and $n=681$ for member associations. Most of these dropouts were related to incorrect email addresses caused by typing mistakes or by the fact that the corresponding person no longer belonged to the institution. In total, $n=574$ private firms and $n=1,165$ member associations participated in the survey. The response rate was $35.9 \%$ for private firms and $41.4 \%$ for member associations. These response rates were relatively 
high compared to those of previous online surveys of sporting organizations (e.g., Breuer \& Haase, 2007; Breuer \& Wicker, 2009).

The invitation e-mails informed the respondents that the survey was anonymous and that the data were treated confidentially and only used in relation to the Sport Development Report. The e-mails contained a personalized link to the online questionnaire. As a result, each institution had its own online questionnaire, which meant that the respondents could log in and out. Thus, the questionnaire did not have to be filled out in one sitting, and several persons were able to fill in the data. For example, the president of a member association could respond to general questions about the general situation (e.g., the number of members and the organization's problems), and the treasurer could fill in the financial data. Previous Sport Development Reports have revealed that most questionnaires were completed by voluntary board members of the member associations. This information was not available for private firms, as the Sport Development Report is usually restricted to member associations. This particular project presents an exception to the rule.

The online questionnaire consisted of approximately 50 questions. In this study, the questions related to the finances of the private firms and the member associations are most important. In particular, the sponsorship revenues of the sports institutions hold particular interest for this research. The online questionnaire asked the respondents to describe the annual revenues and expenditure of the institution. Moreover, respondents were asked to state whether the institution had revenues or expenses in several categories. For example, the revenue categories included revenues from membership fees/royalties, public subsidies, service fees, and sponsorships. Sponsorship revenues included revenues from periphery advertisements, print advertisements, and jerseys and equipment. The questionnaire asked both the private firms and the member associations to describe their sponsorship revenues such that a comparison could be made between these two types of institutions. The financial data in the study refer to 2008, which is the year before the survey was administered.

\section{Data Analysis}

The data analysis consisted of two main steps. First, the descriptive statistics of the private firms' and the member associations' general characteristics (e.g., customers/members, horses, coaches, paid staff, and tournaments) were presented. This study selected these characteristics to portray the structure of the institutions. The financial characteristics to be studied were annual expenditure, annual revenues, sponsorship income, and proportion of sponsorship income. Independent samples $t$-tests were conducted to test for significant differences between private firms and member associations.

Next, regression analyses were conducted. Altogether, three regression models were estimated. The first model (Model 1) was a logistic regression analysis with the variable sponsorship income dummy as the dependent variable. In the second model (Model 2), the proportion of sponsorship income served as the dependent variable. The variables customers/members, horses, coaches, paid staff, tournaments, annual expenditure, and annual revenues were included as independent variables (controls) in both regression models. The variable sponsorship income was not used as the dependent variable because this model might suffer from the fact that size (e.g., number of members/customers, annual expenditure, annual revenues) determines size (amount of 
sponsorship income). Regression models with robust standard errors were estimated to control for heteroscedasticity (MacKinnon \& White, 1985; White, 1980). An $\alpha$-level of .05 was used for all statistical tests.

The third regression model (Model 3) was supposed to be a two-stage-least-squares (2SLS) model with the proportion of sponsorship income as the dependent variable. An anonymous referee noted that there might be endogeneity problems because the variable legal structure is a choice variable. He suggested using an instrumental variable such as population density for this potentially endogenous variable. Therefore, a measure for population density (number of inhabitants in the community of the sports institution) was manually included in the dataset. The population density was a valid instrument in a previous study on professional road running (Frick \& Prinz, 2007); however, this instrument was less powerful in the current study. The correlation between the legal structure and number of inhabitants was very small $(r=.083$; $p=.049$ ). It must be noted that the positive correlation implies that private firms are more likely to be located in communities with fewer inhabitants. This finding seems plausible because private firms can be agricultural or industrial companies (see research context section). Thus, private firms in amateur equestrian sports differ from private firms in other areas like commercial fitness centers, which are more likely to be located in cities with more inhabitants. Moreover, the first stage $F$-value for the instrument should exceed 10 (Stock, Wright, \& Yogo, 2002), which was not the case $(F=.512$; $p=.475)$. Given the weakness of the instrument, the 2SLS model could not be run. No other instrumental variable could be found, unfortunately. The problem of finding valid instruments is not unique to the current study because previous studies in other areas shared this problem (Murray, 2006). Another possibility was to use the residuals as instruments. This procedure has already been applied in previous research (e.g., Frick, 2001; Lehmann \& Schulze, 2008) and was also used in this study. The variable annual expenditure had to be excluded from the third model due to multicollinearity problems.

\section{Results}

The descriptive statistics and the results of the $t$-test are summarized in Table 2. A comparison of the general characteristics showed that the member associations in German amateur equestrian sports had significantly more members than the private firms. On average, the private firms had 115.3 customers, whereas the member associations had 146.2 members. Although the private firms had fewer customers, their average number of horses was significantly higher (36.5 vs. 10.7 horses). Moreover, the private firms had significantly more coaches on average than the member associations (2.1 vs. 1.6 coaches). They were also characterized by a more professional structure, in that they were more likely to employ paid staff: approximately two-thirds $(65.1 \%)$ of the private firms employed paid staff, whereas only $29.7 \%$ of the member associations had paid staff. In contrast, the member associations were more likely to organize tournaments: almost two-thirds $(65.1 \%)$ of the member associations organized a tournament in 2008. This percentage was smaller for the private firms (25.6\%); however, the difference was not statistically significant (Table 2).

A comparison of financial characteristics showed that the private firms had significantly higher annual expenditure and annual revenues than the member associations, 
The Effect of a Sports Institution's Legal Structure on Sponsorship Income

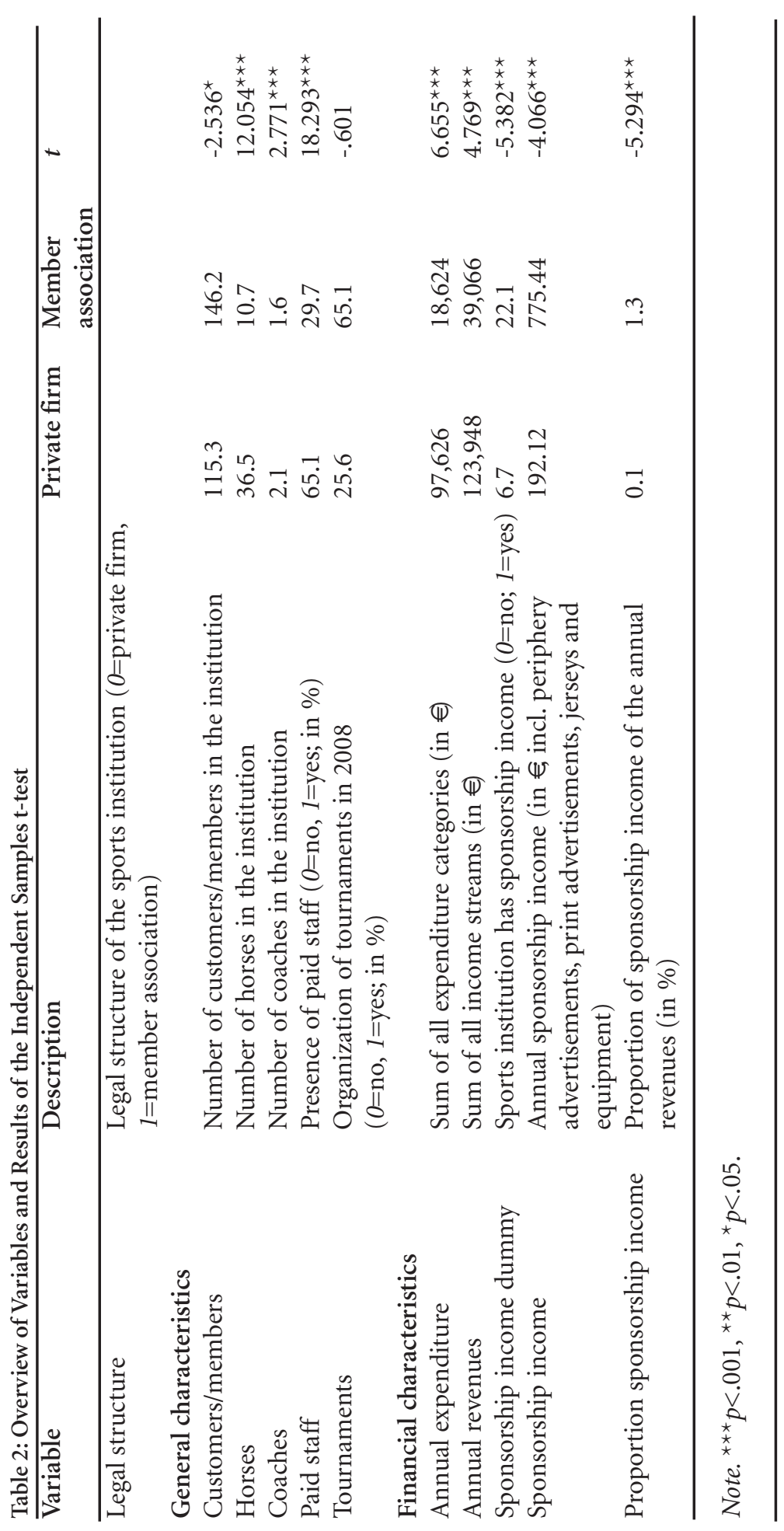

Volume $7 \cdot$ Number $4 \cdot 2012 \cdot$ IJSF 351 
although they were smaller in terms of the number of customers. The sponsorship income differed significantly between private firms and member associations. Only $6.7 \%$ of the private firms received sponsorship income, whereas $22.1 \%$ of the member associations generated this type of revenue. The average sponsorship income amounted to approximately $€ 92$ for private firms and approximately $€ 75$ for member associations; this difference was statistically significant. In private firms, only $0.1 \%$ of the annual revenues consisted of sponsorship income. This proportion was significantly higher in member associations, where $1.3 \%$ of the annual revenues came from sponsorships (Table 2).

The results of the regression analyses are presented in Table 3. The results showed that legal structure had a significant impact on the dependent variable in both models. The positive nature of the effect suggested that member associations received higher sponsorship income than private firms when all other variables are controlled. In addition to the legal structure, the variables tournaments, annual expenditure, and annual revenues had a significant influence on whether the sports institution generated sponsorship income (Model 1). The influence of the variable annual expenditure was negative, whereas the variables tournaments and annual revenues had a positive effect. In the second model (Model 2), only the presence of paid staff in the institution significantly impacted the proportion of sponsorship income in addition to the legal structure. In the third model (Model 3), the exogenous variable legal structure still had a significant impact on the proportion of sponsorship income (Table 3). In summary, the regression results confirmed the previous hypothesis that member associations received higher sponsorship income than private firms.

Table 3: Summary of Regression Results

\begin{tabular}{llll}
\hline & $\begin{array}{l}\text { Model 1: } \\
\text { Sponsorship } \\
\text { income dummy }\end{array}$ & $\begin{array}{l}\text { Model 2: } \\
\text { Proportion } \\
\text { sponsorship } \\
\text { income }\end{array}$ & $\begin{array}{l}\text { Model 3: } \\
\text { Proportion } \\
\text { sponsorship } \\
\text { income }\end{array}$ \\
\hline $\begin{array}{l}\text { Legal structure } \\
\text { Legal structure }\end{array}$ & $1.558(2.61)^{\star *}$ & $.708(3.66)^{\star * *}$ & $/$ \\
(exogenous) & $/$ & $/$ & $1.143(2.78)^{\star *}$ \\
Customers/members & $.001(1.12)$ & $.001(.76)$ & $.001(1.12)$ \\
Horses & $-.003(-.91)$ & $.001(.23)$ & $-.001(-.12)$ \\
Coaches & $-.002(-.08)$ & $-.021(-1.23)$ & $-.012(-.25)$ \\
Paid staff & $.065(.41)$ & $.007(3.95)^{\star * *}$ & $-.345(-.93)$ \\
Tournaments & $.652(2.51)^{\star}$ & $.241(1.05)$ & $.658(1.82)$ \\
Annual expenditure & $-.000(-2.47)^{\star}$ & $-.000(-1.19)$ & $/$ \\
Annual revenues & $.000(2.47)^{\star}$ & $.000(1.22)$ & $-.000(-.37)$ \\
Constant & $-3.980(-6.76)^{\star * *}$ & $-.061(-.48)$ & $.693(3.376)^{\star * *}$ \\
$R^{2}$ & .124 & .015 & .023 \\
\hline
\end{tabular}

Note. Displayed are the coefficients, $z$-values (Model 1 ) or $t$-values (Models 2 and 3 ) in brackets; ${ }^{* * *} p<.001,{ }^{* *} p<.01,{ }^{*} p<.05$. 


\section{Discussion}

This empirical study provided evidence that institutions structured as member associations receive higher sponsorship income than those organized as private firms, using the example of amateur equestrian sports in Germany. These findings indicate that a theoretical framework based on platform theory and property rights theory is effective not only for professional sports but also for amateur sports. The confirmed hypothesis indicates that sponsors prefer to invest in cooperation with member associations. As argued in this article, one explanation for this preference may be that the lower risk of hold-up problems and the greater amount of attention directed towards the sponsor make member associations superior advertising targets compared with private firms (Table 1). Additional explanations are also possible. For example, it is possible that the customers of private firms are willing to pay higher fees to avoid the involvement of sponsors. Given a lower fee income potential in member associations, these organizations are required to raise money from sponsors to be able to offer the requested services. ${ }^{2}$ However, this argument supports the basic hypothesis of this paper-that legal structure affects the composition of revenues. Using the theoretical framework presented here, an avoidance of sponsors by the customers is a negative cross-side effect from sponsors to customers/members.

Another explanation of these findings could be that customers/members self-select into a specific type of organization. Problems regarding horse-specific investments (hold-up problems) should be less severe in member associations, if it is assumed that the government supports them financially to ensure that they do not go bankrupt. This might be true for professional sports, and specifically for professional football clubs, as recently proven by the FC Dynamo Dresden, a football club in the second division of the German Bundesliga. The city of Dresden provided substantial financial support for the club to avoid its insolvency. However, such bailouts are rare in amateur sports. Hundreds of member associations are insolvent every year and must declare bankruptcy (Geckle, 2003). Furthermore, it could be argued that member associations put more effort into generating sponsorship income because this income stream is one of their most important sources of income. Again, this might be the case for professional football clubs, such as Bayern Munich and Manchester United, where sponsorship revenues constitute an important revenue category (Deloitte, 2010). However, previous research has shown that the composition of the income portfolio of member associations in amateur sports is different. Revenues from membership fees were found to be the most important income source for member associations across sports (Breuer \& Wicker, 2009) as well as in football and equestrian sports (Breuer \& Wicker, 2011).

This study has some limitations that may be addressed by future research. First, the study is limited to one specific sport (i.e., equestrian). Future researchers may apply this analysis to other amateur sports, such as football or ice hockey. However, comparisons between member associations and private firms are more difficult in other sports because both types of legal structures are not members of the same umbrella organization. Because the study is restricted to one sport, only careful generalizations can be made. A second limitation of the study is related to the reasons for sponsorships. Although explained in the theoretical literature, the reasons why companies sponsor member associations and private firms are still unclear. This information is not cov- 
ered by the data in this study. Qualitative research may help to clarify the reasons for sponsorships and support the theoretically derived hypothesis. As it stands, the legal structure variable represents a proxy for these aspects. Another limitation relates to the low $R^{2} \mathrm{~S}$ in the regression models. They show that the models only explain $1.5 \%$ (Model 2), 2.3\% (Model 3), and 12.4\% (Model 1) of the variance of the dependent variable. One reason for the low $R^{2}$ s could be the cross-sectional character of the study. $R^{2}$ s are usually higher in panel studies because several points of measurements are available, which increases the $R^{2}$ (Keith, 2006). Moreover, the purpose of this study was not to find a set of variables that best explains sponsorship income, but rather to analyze whether the legal structure of an institution has a significant impact on sponsorship income.

Despite the aforementioned limitations, the findings of this study have some implications for the managers of sports organizations. Managers and sports institutions face a difficult choice with regard to the legal structure of their institution. Although private firms are usually thought to be more efficient and exhibit advantages in other revenue streams, member associations outperform these private firms with regard to sponsorship revenues. Managers must consider this aspect when making decisions about the organization's legal structure. Further research is needed to determine whether additional revenue categories exist that are also influenced by the legal structure. Moreover, member associations should be aware of the advantages that they have when compared with private firms. When member associations talk to potential sponsors, they should emphasize these benefits to the sponsor. Doing so is particularly important, as sponsorship revenues might become more important in the next few years. Many member associations receive government subsidies from the federal state, the district, or the community government. Because many public authorities are experiencing financial problems in Germany, government subsidies are likely to decrease in the next several years. Indeed, a reduction in the public subsidies for sports institutions has already been observed in recent years (Federal Statistical Office, 2007). Therefore, member associations should look to other revenue sources, such as sponsorships, to compensate for the loss in revenues from public subsidies.

\section{Conclusion}

The choice of legal structure is an important decision for an institution. Many institutions face a choice between profit-oriented private firms and non-profit member associations. This study focused on one aspect that has been neglected to date: the impact of a sports organization's legal structure on its sponsorship revenues. This paper conducted an empirical analysis by studying the case of amateur equestrian sports institutions in Germany. Based on platform theory and property rights theory, this study derived the following hypothesis: sports institutions structured as member associations have higher sponsorship revenues than those organized as private firms. The hypothesis was confirmed by the regression results. Managers must consider this aspect when making decisions about the legal structure of their institutions. 


\section{References}

Alchian, A. (1977). Some economic forces at work. In A. Alchian \& R. Coase (Eds.), Economic forces at work (pp. 127-149). Indianapolis, IN: Liberty Press.

Armstrong, M. (2006). Competition in two-sided markets. RAND Journal of Economics, 37(3), 668-691.

Bakos, Y., \& Katsamakos, E. (2008). Design and ownership of two-sided networks: Implications for internet platforms. Journal of Management Information Systems, 25(2), 171-202.

Breuer, C., \& Haase, A. (2007). Methode. In C. Breuer (Ed.), Sportentwicklungsbericht 2005/2006 - Analyse zur Situation der Sportvereine in Deutschland (pp. 641-663). Cologne, Germany: Sport und Buch Strauß.

Breuer, C., \& Wicker, P. (2009). Sports clubs in Germany. In C. Breuer (Ed.), Sport Development Report 2007/2008. Analysis of the sports clubs' situation in Germany. Abbreviated Version (pp. 5-50). Cologne, Germany: Sportverlag Strauß.

Breuer, C., \& Wicker, P. (2011). Die Situation der Sportarten in Deutschland - Eine Analyse der Sportvereine in Deutschland auf Basis der Sportentwicklungsberichte. Cologne, Germany: Sportverlag Strauß.

Daly, G., \& Moore, W. (1981). Externalities, property rights and the allocation of the resources in Major League Baseball. Economic Inquiry, 19(1), 77-95.

Deloitte (2010). Annual review of football finance. Manchester, UK: Deloitte.

Demsetz, H., \& Lehn, K. (1985). The structure of corporate ownership: Causes and consequences. Journal of Political Economy, 95, 1155-1177.

Demsetz, H., \& Villalonga, B. (2001). Ownership structure and corporate performance. Journal of Corporate Finance, 7, 209-233.

Dietl, H. (2010). Erfolgsstrategien im plattformwettbewerb. Schmalenbachs Zeitschrift für betriebswirtschaftliche Forschung, Special Issue 62/10, 63-83.

Dietl, H., \& Duschl, T. (2009). The organization of professional sports leagues: A comparison of European and North American leagues from the perspective of platform organization. Working Paper No. 119, University of Zurich, Institute for Strategy and Business Economics.

Dietl, H., \& Weingärtner, C. (2011). The effect of professional football clubs' legal structure on sponsoring revenue. Journal of Sponsorship, 4(4), 377-390.

Dilger, A. (2009). Im verein ist es am schönsten - warum vereine kapitalgesellschaften im sport überlegen sind. Sportwissenschaft, 39(2), 137-142.

Eisenmann, T., Parker, G., \& van Alstyne, M. (2006). Strategies for two-sided markets. Harvard Business Review, 84(10), 92-101.

Eisenmann, T., Parker, G., \& van Alstyne, M. (2008). Opening platforms how, when and why? Working Papers - Harvard Business School Division of Research, 1-27.

Federal Statistical Office (2007). Ausgaben des bundes und der länder für den sport von 1975 bis 2004. Wiesbaden, Germany: Federal Statistical Office.

Felderer, B., Helmenstein, C., Kleissner, A., Moser, B., Schindler, J., \& Treitler, R. (2006). Sport und Ökonomie in Europa. Studie im auftrag des bundeskanzleramts, sektion sport. Wien, Austria: Bundeskanzleramt.

Franck, E. (2010a). Private firm, public corporation or member's association-Governance structures in European football. International Journal of Sport Finance, 5(2), 108-127.

Franck, E. (2010b). Zombierennen und patenonkel—Warum deutsche fussballklubs in der champions league den kürzeren ziehen. Schmalenbachs Zeitschrift für betriebswirtschaftliche Forschung (zfbf), 62, 1-13.

Frick, B. (2001). Die einkommen von 'superstars' und 'wasserträgern' im professionellen teamsport: Ökonomische analyse und empirische befunde. Zeitschrift für Betriebswirtschaft, 71, 701-720. 
Frick, B. (2004). Does ownership matter? Empirical evidence from the German wine industry. KYKLOS, 57(3), 357-386.

Frick, B., \& Prinz, J. (2007). Pay and performance in professional road running: The case of city marathons. International Journal of Sport Finance 2(1), 25-35.

Geckle, G. (2003). Zur insolvenzsituation bei vereinen und verbänden. In G. Trosien \& M. Dinkel (Hrsg.), Grenzen des sportkonsums: Sportmarketing - sportstandort - sportstätte (pp. 49-65). Butzbach-Griedel, Germany: Afra.

Hansmann, H. (1986). The role of nonprofit enterprise. In S. Rose-Ackerman (Ed.), The economics of nonprofit institutions. Studies in structure and policy ( $\left.2^{\text {nd }} \mathrm{ed} ., \mathrm{pp} .57-84\right)$. New York, NY: Oxford University Press.

Himmelberg, C. P., Hubbard R. G., \& Palia, D. (1999). Understanding the determinants of managerial ownership and the link between ownership and performance. Journal of Financial Economics, 53, 353-384.

Horch, H.-D. (1992). Geld, macht und engagement in freiwilligen vereinigungen. Grundlage einer wirtschaftssoziologie von non-profit-organisationen. Berlin, Germany: Duncker \& Humblot.

Horch, H.-D. (1994). On the socio-economics of voluntary associations. Voluntas, 5(2), 219-230.

Karpoff, J. M. (2001). Public versus private initiative in Arctic exploration: The effects of incentives and organizational structure. Journal of Political Economy, 109, 38-78.

Keith, T. Z. (2006). Multiple regression and beyond. Boston, MA: Pearson.

Kicker (2010). 50+1: Kind kämpft weiter. Retrieved from http://www.kicker.de/news/fussball/bundesliga/startseite/520511/artikel_502b1_Kindkaempft-weiter.html

Lehmann, E. E., \& Schulze, G. G. (2008). What does it take to be a star? The role of performance and the media for German soccer players. Applied Economics Quarterly, 54(1), 59-70.

Lepak, D., Smith, K., \& Taylor, S. (2007). Value creation and value capture: A multilevel perspective. Academy of Management Review, 32(1), 180-194.

MacKinnon, J. G., \& White, H. (1985). Some heteroskedasticity-consistent covariance matrix estimators with improved finite sample properties. Journal of Econometrics, 29(3), 305-325.

Marburger, D. (2002). Property rights and unilateral player transfers in a multiconference sports league. Journal of Sports Economics, 3(2), 122-132.

Milgrom, P., \& Roberts, J. (1992). Economics, organization and management. Upper Saddle River, NJ: Prentice Hall.

Murray, M. P. (2006). Avoiding invalid instruments and coping with weak instruments. Journal of Economic Perspectives, 20(4), 111-132.

Picot, A. (1981). Der beitrag der theorie der verfügungsrechte zur ökonomischen analyse von unternehmensverfassungen. In K. Bohr, J. Drukarczyk, H.-J. Drumm, \& G. Scherrer (Eds.), Unternehmensverfassung als problem der betriebswirtschaftslehre (pp. 153-197). Berlin, Germany: Erich Schmidt.

Picot, A., Dietl, H., \& Franck, E. (2008). Organisation. Eine ökonomische perspektive. (5 ${ }^{\text {th }}$ ed.). Stuttgart, Germany: Schäffer-Poeschel.

Picot, A., \& Michaelis, E. (1984). Verteilung von verfügungsrechten in grossunternehmen und unternehmensverfassung. Zeitschrift für Betriebswirtschaft, 54, 252-272.

Richter, R., \& Furubotn, E. (2010. Neue institutionenökonomik. Eine einführung und kritische würdigung. ( $4^{\text {th }}$ ed.). Tübingen, Germany: Mohr Siebeck.

Rochet, J., \& Tirole, J. (2002). Cooperation among competitors: Some economics of payment card associations. RAND Journal of Economics, 33(4), 1-22.

Rochet, J., \& Tirole, J. (2003). Platform competition in two-sided markets. Journal of the European Economic Association, 1(4), 990-1029.

Rochet, J., \& Tirole, J. (2006). Two-sided markets: A progress report. RAND Journal of Economics, 37(3), 645-667. 
Rysman, M. (2009). The economics of two-sided markets. Journal of Economic Perspectives, 23(3), 125-143.

Stock, J. H., Wright, J. H., \& Yogo, M. (2002). A survey of weak instruments and weak identification in generalized method of moments. Journal of Business \& Economics Statistics, 20(4), 518-529.

White, H. (1980). A heteroscedasticity-consistent covariance matrix estimator and a direct test for heteroscedasticity. Econometrica, 48(4), 817-838.

Zeithaml, V. (1988). Consumer perception of price, quality and value: A means-end model and synthesis of evidence. Journal of Marketing, 52(July), 2-22.

\section{Endnotes}

${ }^{1}$ With the VfL Wolfsburg and Bayer Leverkusen, there are two exemptions to this rule due to historic reasons. The owners are the public companies Volkswagen and Bayer. However, neither is allowed to sell more than $49 \%$ of their shares to an external investor.

${ }^{2}$ We thank an anonymous IJSF reviewer for the valuable suggestion of this alternative explanation. 
Reproduced with permission of the copyright owner. Further reproduction prohibited without permission. 